\title{
Pyroclastic deposits and volcanic history of Mayor Island
}

\author{
M. D. BUCK* \\ R. M. BRIGGS \\ CAMPBELL S. NELSON \\ Earth Sciences Department \\ University of Waikato \\ Private Bag \\ Hamilton, New Zealand
}

Abstract The emergent summit of Mayor Island Bay of Plenty, New Zealand, is a peralkaline rhyolite volcano constructed by: a sequence of lava flows, the Tutaretare Rhyolite Formation (new); and pyroclastic deposits, the Oira Pyroclastite Formation (new). These 2 formations constitute the Mayor Island Group (new). The pyroclastic deposits mantle most of the outer slopes of the island, in places exceeding $100 \mathrm{~m}$ in thickness, and also occur interbedded with lava flows of the main cone. The pyroclastics have been informally assigned on the basis of their compositional, welding and textural, and sedimentary structural characteristics to one or other of 15 lithotypes which may be related to particular modes of eruption and emplacement, of both airfall (phreatic, phreatomagmatic, phreatoplinian, and plinian types) and pyroclastic flow (ignimbrite, nuee ardente, and base surge types) origins. A sixteenth lithotype comprises epiclastic deposits formed possibly by catastrophic overspill from an ancestral crater lake. Two new radiocarbon dates on logs from the pyroclastic deposits are recorded: (Wk105) $8000 \pm 70$ years B.P., and (Wk77) $6340 \pm 190$ years B.P. Recognition of the calcalkaline Rotoehu and possibly Rotoma Ashes on Mayor Island, together with the new radiocarbon dates, enables definition of 8 phases of major volcanic activity, each separated by relatively quiescent periods with erosion and paleosol formation. Volcanism commenced sometime prior to 42000 years ago and has continued intermittently up to the eruption of the young dome lavas, possibly less than 1000 years ago. At present, only 1 Miayor Island-derived tephra has been identified on the mainland of the North Island, namely the Tuhua Tephra dated (Wk77) at source as $6340 \pm 190$ years B.P. However, the character and magnitude of several of the pyroclastic units on Mayor Island is such that recognition of other peralkaline tephras is anticipated in northern. North Island.

*Present address: School of Earth Sciences, Macquarie University, North Ryde, N.S.W., Australia 2113.

Received 17 February 1981, accepted 5 Augüst 1981
Keywords pyroclastics; volcanology; volcanoes; radiocarbon dating; Mayor Island; Mayor Island Group; Tutaretare Rhyolite Formation; Oira Pyroclastite Formation; Otura Fault; new stratigraphic names

\section{INTRODUCTION}

Mayor Island is the emergent summit of an isolated peralkaline rhyolite volcano lying near the edge of the continental shelf about $26 \mathrm{~km}$ offshore in western Bay of Plenty, North Island, New Zealand. It forms a composite volcanic cone built up of thick lava flows and pyroclastic pumice deposits and rises from about the $330 \mathrm{~m}$ isobath, where it is over $15 \mathrm{~km}$ across, to $355 \mathrm{~m}$ a.s.1. at Opuahau peak. The island is roughly circular, with a diameter of about $4 \mathrm{~km}$, surmounted by a large $3 \mathrm{~km}$ diameter circular caldera.

The peralkaline rhyolite composition of the volcanic and pyroclastic rocks contrasts markedly with the generally calcalkaline character of the nearby Taupo Volcanic Zone. Mayor Island is situated approximately above the $-200 \mathrm{~km}$ contour on the Benioff Zone that dips northwest beneath the North Island (Adams \& Ware 1977), and lies on the southwesterly extension of the interarc Lau-Havre Basin. Smith et al. (1977) and Cole (1978) have suggested that the peralkaline rhyolites record the impingement of a tensional rift on the developed crust of the North Island.

Most previous geological studies on Mayor Island have been concerned with either the landforms and volcanic history (e.g., Marshall 1936; Cotton 1941; Brothers 1957) or especially the petrography and chemistry of the peralkaline rhyolite lavas (e.g., Thomson 1926; Bartrum 1926; Marshall 1936; Ewart 1965; Ewart et al. 1968; Nicholls \& Carmichael 1969; Bailey \& Macdonald 1976; Rutherford 1978). Pyroclastic deposits form a thick mantle over much of Mayor Island and occur interbedded with lava flows, but despite their areal and volumetric importance they have received only passing mention. Several detailed stratigraphic sections through the pyroclastic deposits and associated volcanics have been compiled by Buck (1978) and the location of some of these sites is shown in Fig. 1. The aim of this paper is to document the distribution and general characteristics of the pyroclastic deposits and to refine Brother's (1957) volcanic history of Mayor Island. 


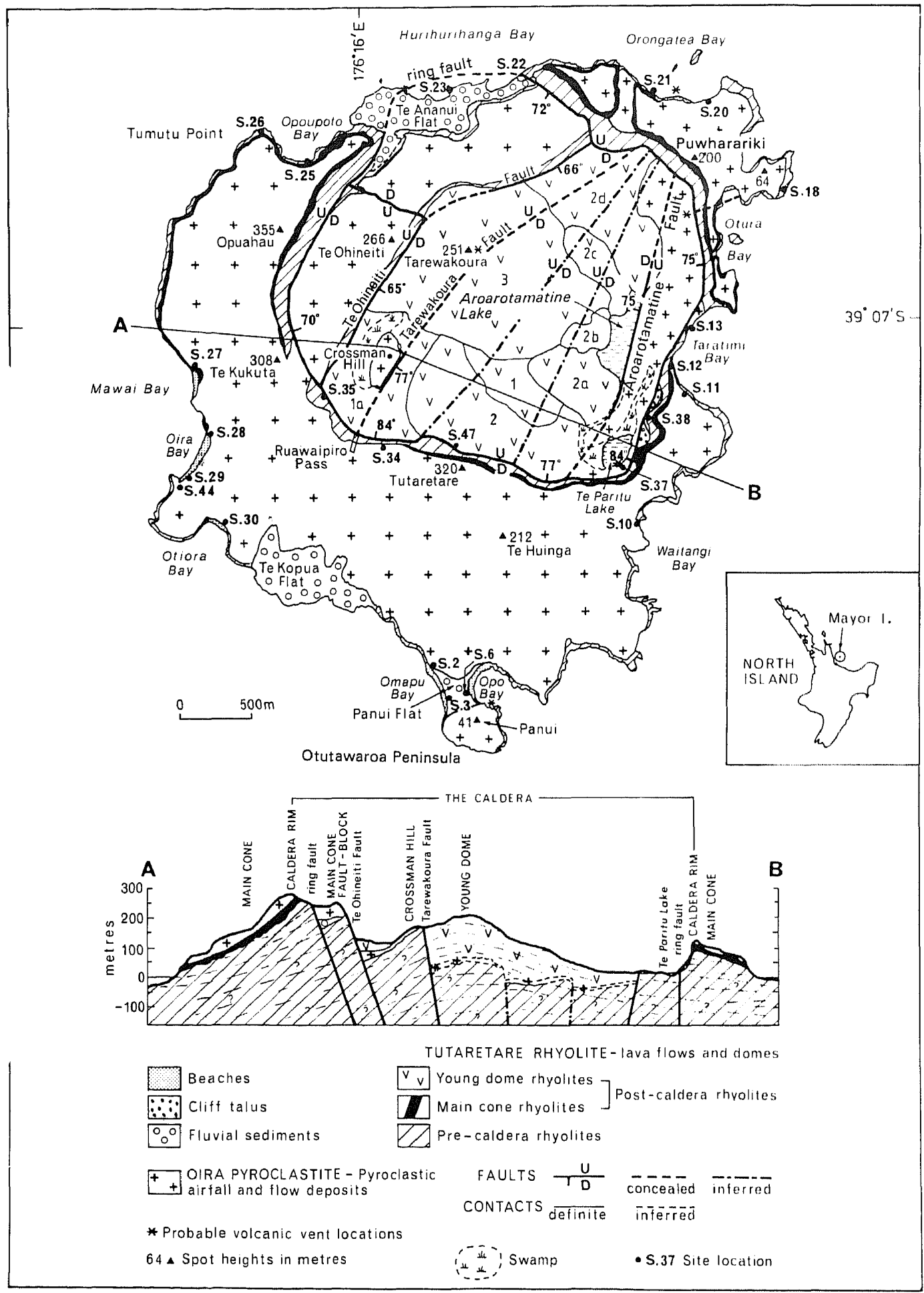

ig. 1 Geological map and diagrammatic east-west cross section of Mayor Island, Bay of Plenty, New Zealand. 


\section{STRATIGRAPHIC NOMENCLATURE}

The peralkaline extrusive rocks of Mayor Island are collectively named the Mayor Island Group (new) and are divided into 2 formations depending on whether they are dominantly lava flows (the Tutaretare Rhyolite Formation) or pyroclastic deposits (the Oira Pyroclastite Formation).

The Tutaretare Rhyolite Formation (new) includes all the peralkaline lava flows on the island (Fig. 1). The type section is in the south wall of the caldera, beneath Tutaretare peak (Section 47), where 5 separate flow units are well exposed. According to the peralkaline rock classification of Macdonald (1974) the rhyolites of Mayor Island are dominantly pantellerites with only minor comendites. On the geological map, the Tutaretare Rhyolite is subdivided informally into pre- and postcaldera rhyolites (Fig. 1).

The Oira Pyroclastite Formation (new) includes all pyroclastic deposits of both airfall and pyroclastic flow origin on Mayor Island. The formation name is derived from the type section at Oira Bay (Section 28-29) where the pyroclastic sequence is the most complete (Fig. 2). The Oira Pyroclastite includes 16 informally recognised lithotypes that are defined in a later section.

\section{GEOLOGY AND STRUCTURE OF MAJOR PHYSIOGRAPHIC UNITS}

Brothers (1957) distinguished 3 major landforms on Mayor Island: the main cone, the old dome, and the young dome; built during successive periods of volcanic activity. Here we modify slightly and extend Brother's scheme to include 4 major physiographic units: the main cone, the caldera fault blocks, the young dome, and the coastal flats (Fig. 1).

\section{Main cone}

The main cone forms the principal outer slopes of the island, rising from spectacular coastal cliffs, up to $110 \mathrm{~m}$ high, to the major peaks of Opuahau (354 $\mathrm{m})$, Te Kukuta $(308 \mathrm{~m})$, and Tutaretare $(320 \mathrm{~m})$ which lie on the perimeter of the caldera wall. Deeply incised, ephemeral, radiating streams have partly eroded the main cone, the largest now forming Ruawaipiro Pass. Near Te Ananui Flat on the northern coast, catastrophic flooding from an ancestral crater lake (see later) and marine erosion have removed a section of the main cone and breached the caldera wall.

The bulk of the main cone is constructed of planezes of flow banded, vesicular rhyolite flows up to $40 \mathrm{~m}$ thick, with obsidian selvedges on their upper (av. $4 \mathrm{~m}$ thick) and lower (av. $1.5 \mathrm{~m}$ thick) surfaces. On the northern and eastern coasts of the island the youngest lavas dip seawards at $25-30^{\circ}$ and unconformably overlie more gently dipping $\left(5-10^{\circ}\right)$ older flows. The rhyolites are glassy or cryptocrystalline to microcrystalline, often microspherulitic, and contain generally less than $4 \%$ phenocrysts of anorthoclase, aegirine-hedenbergite, and aenigmatite, with or without quartz, riebeckite, or plagioclase.
Fig. 2 Stratigraphic columns of the pyroclastic sequences at Oira Bay (site 28, Oira Pyroclastite type section), North Taratimi Bay (site 13), and Ruawaipiro Pass (site 34 ). $\mathrm{Rm}=$ possibly Rotoma Ash; Tu = Tuhua Tephra; L1, L2 etc. are lithotypes $1-16$ of the Oira Pyroclastite Formation.

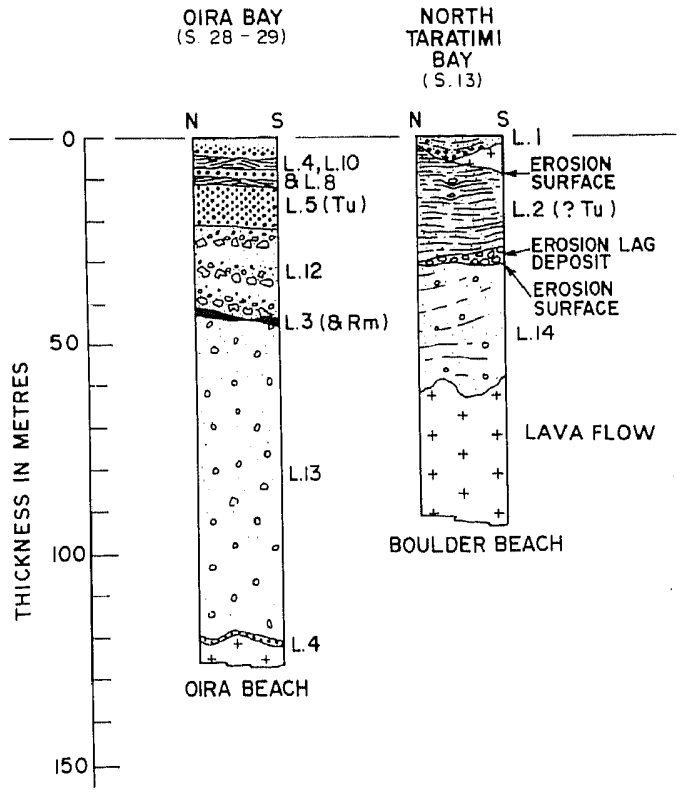


The lava flows of the main cone are mantled by thick deposits of Oira Pyroclastite. Pyroclastic flow units are the most voluminous and sequences up to $80 \mathrm{~m}$ thick infill former topographic lows (e.g., sites $20,27-29$, and 30 ). Intercalated between most of the lava flows of the main cone are thin $(<4 \mathrm{~m})$ deposits of airfall pumice tephra, as shown in the typical Opoupoto Bay section (Fig. 3), but pyroclastic flow units up to $50 \mathrm{~m}$ thick also occur (e.g., sites 11-13).

A large normal fault, named the Otura Fault (new), with a throw in excess of $100 \mathrm{~m}$, displaces lavas and interbedded pyroclastics of the main cone at the northern end of Otura Bay. The Otura Fault is largely concealed at the surface. It is unconformably overlain by a younger lava flow, and is the site of a near vertical narrow dike which intrudes along the fault, striking $070^{\circ}$.

\section{Caldera fault blocks}

The caldera wall delimits a near-circular ring fracture about $3 \mathrm{~km}$ in diameter centred slightly towards the northeastern sector of the island. The ring faults have throws up to $200 \mathrm{~m}$, and dip inwards at angles varying from $65^{\circ}$ near Opuahau to almost vertical at Tutaretare. The caldera walls are $200 \mathrm{~m}$ high in the south, about $20 \mathrm{~m}$ high at their lowest point at Taratimi Bay, and have been breached in the region of Te Ananui Flat.

Within the caldera a series of at least 3 , and possibly 5 , subparallel north to northeast-striking normal faults cross the caldera floor. The 3 definite faults are named, from west to east, the Te Ohineiti Fault (new), Tarewakoura Fault (new), and the Aroarotamatine Fault (new). The faults are repeatedly downthrown on their eastern side so that the upper surfaces of the fault blocks systematically decrease in height from west to east to form a faultstepped base to the caldera.

\section{Main cone fault block}

The crescent-shaped, highest fault block on the northwestern side of the caldera rises to $266 \mathrm{~m}$ a.s.1. at Te Ohineiti Hill. It is bounded to the west by the caldera wall ring fault and to the east by the $\mathrm{Te}$ Ohineiti Faullt, which forms a prominent fault scarp dipping eastwards at angles of $60-70^{\circ}$. Brothers (1957) called this block a remnant of an "old dome", but we suggest it is the downthrown part of the main cone, because: (1) northwest-southeast cross sections indicate that the surface slope on the fault block is the same as that on the upper slopes of the immediately adjacent main cone; (2) the uppermost lava flow exposed in the Te Ohineiti Fault scarp is petrographically similar to the gently dipping flows in the adjacent main cone (Buck 1978); and (3) the fault block is covered by bedded pyroclastic airfall and flow deposits which can be correlated with those

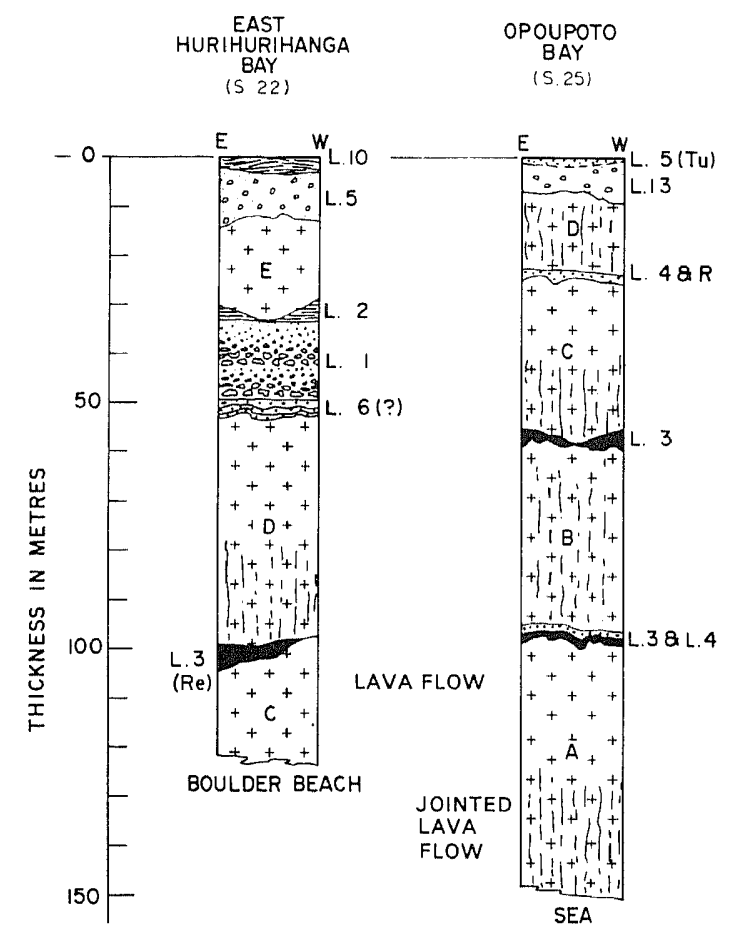

Fig. 3 Stratigraphic columns of the pyroclastic deposits interbedded with pantellerite lava sequences at east Hurihurihanga (site 22) and Opoupoto (site 25) Bays. Re $=$ Rotoehu Ash; Tu = Tuhua Tephra $\mathrm{L}=$ lithotype; $\mathrm{A}$ $\mathrm{E}=$ labelled pantellerite lavas (oldest to youngest).

mantling the main cone. Thus, we interpret the fault block as having been downthrown along the ring fault from its original position on the main cone, with a maximum throw of about $170 \mathrm{~m}$ at Opuahau, and have designated it the Main Cone fault block (see cross section, Fig. 1).

The northern half of the Main Cone fault block has been further downthrown with respect to the southern half by a small ESE $\left(108^{\circ}\right)$ striking fault. Brothers (1957) shows on his geological map a single major fault crossing Mayor Island from Orongatea Bay in the northeast to Otiora Bay in the southwest. However, the cliff sections at both Orongatea and Otiora Bays do not show any clear evidence of such a fault and we suggest that it is restricted in extent to lie within the caldera, and represents the Te Ohineiti Fault defined above.

\section{Crossman Hill fault block}

A second fault block, named the Crossman Hill fault block, lies to the east of Te Ohineiti Fault and is largely buried by lava flows from the young dome. It is exposed in the fault scarp marking the trace of the 
east-dipping $\left(80^{\circ}\right.$ Tarewakoura Fault on the eastern side of Crossman Hill (Fig. 1), and probably consists of main cone lavas mantled by thick pyroclastics.

\section{Te Paritu fault block}

On the eastern side of the caldera a third downthrown block of the main cone probably occurs between the west-dipping $\left(75^{\circ}\right)$ Aroarotamatine Fault, which marks the very straight eastern shore of Aroarotamatine Lake (22 $\mathrm{m}$ deep), and the caldera ring fracture. The surface of the fault block is flat due to a mantle of pumiceous pyroclastics, and lies 5-10 $\mathrm{m}$ a.s.l., suggesting the throw along the ring fault in this region is about $120 \mathrm{~m}$. The $9 \mathrm{~m}$ deep Te Paritu Lake, from which the fault block is named, occupies a small surface depression towards the southern end of the block.

\section{Other fault blocks}

Aroarotamatine Lake possibly occupies a surface depression of a further (unnamed) fault block that has been completely buried by lavas of the young dome. The distance between the Tarewakoura and Aroarotamatine Faults, and the respective surface heights of the Crossman Hill and Te Paritu fault blocks suggest that possibly 2 further faults of similar trend occur between them (Fig. 1). The NNE-striking intra-caldera faults all appear to converge northwards and their increasing dip towards the centre of the caldera implies that they also converge with depth.

\section{YOUNG DOME}

The young dome is constructed of a series of overlapping viscous block lava flows which have been consecutively numbered by Brothers (1957) according to their order of eruption (Fig. 1) determined from overlapping and geomorphic evidence on aerial photographs. The flows are typically very steep sided and lobate in outline, have a slightly convex surface in their central portion, and consist of dark glassy rhyolite blocks and vesiculated lava. At least 8 flows occur which have spread east and southeast across the caldera, the youngest rising to a height of $251 \mathrm{~m}$ at Tarewakoura, and all notably lack any airfall pyroclastic cover. The rhyolites of the young dome consist mainly of fresh glass with up to 12 modal percent phenocrystic anorthoclase, quartz, aenigmatite, and aegirine.

\section{COASTAL FLATS}

Te Ananui Flat

Te Ananui Flat is a narrow, fan-shaped area of gently undulating ground lying within the breached caldera wall on the northern side of the island. Te Ananui Flat lies generally about $50 \mathrm{~m}$ a.s.l., although it rises gradually to the south in the valley separating the main cone and the Main Cone fault block, and is constructed of coarse-grained, fluvial, epiclastic sediments which are exposed in $10-20 \mathrm{~m}$ high cliffs along the coastline.

\section{Te Kopua Flat}

Te Kopua Flat lies on the southwestern side and is constructed of similar epiclastic sediments to $\mathrm{Te}$ Ananui Flat. It forms a broad, shortened fan and rises from the coast up towards Ruawaipiro Pass.

\section{Panui Flat}

Panui Flat is a narrow, flat area of ground, $10-15 \mathrm{~m}$ a.s.l., which connects a small parasitic cone at Panui peak on Otutawaroa Peninsula with the flanks of the main cone. The flat is built up of a succession of pyroclastic flows and airfall tephras, and glassy rhyolite flows.

\section{PYROCLASTIC DEPOSITS}

\section{Introduction}

The pyroclastic deposits occur either as thick sequences mantling the slopes of the main cone and Main Cone fault block (Fig. 1) or as generally thinner sequences interbedded with the peralkaline lavas of the main cone (Fig. 3). The deposits have originated from both pyroclastic airfall and pyroclastic flow eruptions and hence there is a wide range of types of deposit. Furthermore, many deposits are not laterally continuous around the island and in many cases lithologically similar deposits recur in the same stratigraphic section, making the division of the Oira Pyroclastite into formal stratigraphic units unacceptable. Consequently we have simply divided the Oira Pyroclastite into similar lithological entities, which in turn reflect similar eruptive mechanisms, that are informally designated as lithotypes. However, each lithotype records only the general characteristics of a deposit as variations in lithology may occur at different outcrops.

Table 1 summarises the 16 major lithotypes of the Oira Pyroclastite.

Lithotypes 1 to 5 in Table 1 represent deposits that are inferred to have originated from pyroclastic airfall eruptions, and the term tephra will be used synonymously for these deposits, following the convention of Williams \& McBirney (1979). The Mayor Island tephras show similar field and textural characteristics to other silicic tephra deposits (e.g., Murai 1961; Lirer et al. 1973), in that they mantle pre-existing topographies, have regular and distinct stratification, generally lack matrix material, and 
Table 1 Major diagnostic features of the 16 lithotypes of the Oira Pyroclastite Formation.

\begin{tabular}{|c|c|c|c|c|c|c|}
\hline Lithotype & $\begin{array}{l}\text { Emplacement } \\
\text { Mechanism }\end{array}$ & $\begin{array}{l}\text { Max.Recorded } \\
\text { Thickness (m) }\end{array}$ & $\begin{array}{l}\text { Composition } \\
\text { Dominant Fragment } \\
\text { Type }\end{array}$ & Welding and Texturet & Primary Sedimentary Structures & $\begin{array}{l}\text { Reference } \\
\text { Site }\end{array}$ \\
\hline 1 & A & 10 & $\begin{array}{l}\text { Accessory lithoidal } \\
\text { pantellerite }\end{array}$ & $\begin{array}{l}\text { Non-we1ded lapilli } \\
\text { and ash. Rare } \\
\text { blocks. }\end{array}$ & $\begin{array}{l}0.1 \text { to } 1 \mathrm{~m} \text { thick plane } \\
\text { para1le1, normal graded } \\
\text { beds. }\end{array}$ & 3 \\
\hline 2 & A & 10 & $\begin{array}{l}\text { Essential pumice } \\
\text { and accessory } \\
\text { Iitholdal pantellerite }\end{array}$ & $\begin{array}{l}\text { Non-welded lapilli } \\
\text { and ash. Common } \\
\text { blocks. }\end{array}$ & $\begin{array}{l}0.3 \text { to } 1 \mathrm{~m} \text { thick plane/wavy } \\
\text { parallel, normal graded beds. } \\
\text { Numerous impact craters. }\end{array}$ & 18 \\
\hline 3 & A & 2 & $\begin{array}{l}\text { Essential glass } \\
\text { shards and crystals }\end{array}$ & Non-weIded ash & $\begin{array}{l}\text { < lm thick plane parallel, } \\
\text { normal graded beds }\end{array}$ & 3 \\
\hline 4 & A & 3 & Essential pumice & $\begin{array}{l}\text { Non-welded lapilli } \\
\text { and fine blocks. } \\
\text { Porous. }\end{array}$ & $\begin{array}{l}<1.5 \mathrm{~m} \text { thick plane parallel } \\
\text { beds showing normal, normal- } \\
\text { reverse, reverse-normal, or } \\
\text { reverse grading. }\end{array}$ & 3,34 \\
\hline 5 & A & 8 & Essential pumice & $\begin{array}{l}\text { Non-welded lapilli } \\
\text { and fine blocks. } \\
\text { Very porous. }\end{array}$ & A single mostly massive unit. & 44 \\
\hline 6 & F & 21 & $\begin{array}{l}\text { Essential pumice, } \\
\text { glass shards and } \\
\text { accessory lithoidal } \\
\text { pantellerite }\end{array}$ & $\begin{array}{l}\text { Partially welded } \\
\text { tuff with common } \\
\text { accretionary lapilli. }\end{array}$ & $\begin{array}{l}<1.5 \mathrm{~m} \text { thick cross-bedded } \\
\text { basal units overlain by } 2-3 \mathrm{~m} \\
\text { thick massive upper units. }\end{array}$ & 38 \\
\hline 7 & F & $>7.5$ & $\begin{array}{l}\text { Accessory glassy } \\
\text { pantellerite and } \\
\text { essential pumice. }\end{array}$ & $\begin{array}{l}\text { Partially welded } \\
\text { lapilli-tuff. }\end{array}$ & A single normal graded unit. & 37 \\
\hline 8 & $\mathrm{~F}$ & 3 & $\begin{array}{l}\text { Essential pumice and } \\
\text { accessory lithoidal } \\
\text { pantellerite }\end{array}$ & $\begin{array}{l}\text { Non-we1ded blocks } \\
\text { and lapilli in ash } \\
\text { matrix. }\end{array}$ & $\begin{array}{l}\text { A single massive unit with } \\
\text { coarser fragments randomly } \\
\text { set in ash matrix. }\end{array}$ & 6 \\
\hline 9 & $\mathbf{F}$ & 9.5 & $\begin{array}{l}\text { Essential pumice, } \\
\text { accessory lithoidal } \\
\text { pantellerite and } \\
\text { obsidian }\end{array}$ & $\begin{array}{l}\text { Non-welded blocks } \\
\text { and lapilli in ash } \\
\text { matrix. }\end{array}$ & $\begin{array}{l}\text { Up to } 3 \mathrm{~m} \text { thick plane non- } \\
\text { parallel beds with marked } \\
\text { inverse grading. }\end{array}$ & 2 \\
\hline 10 & F & 10 & $\begin{array}{l}\text { Accessory lithoidal } \\
\text { and glassy partell- } \\
\text { erite and obsidian }\end{array}$ & $\begin{array}{l}\text { Incipient to non- } \\
\text { welded lapiIli and } \\
\text { ash. }\end{array}$ & $\begin{array}{l}\text { Well developed low anglo } \\
\left(2-5^{\circ}\right) \text { planar and less } \\
\text { commonly trough cross-beds. }\end{array}$ & 11 \\
\hline 11 & $\mathbf{F}$ & 10.5 & $\begin{array}{l}\text { Accessory lithoidal } \\
\text { pantellerite and } \\
\text { accretionary lapilli }\end{array}$ & $\begin{array}{l}\text { Incipiently welded } \\
\text { lapilli-tuff. }\end{array}$ & $\begin{array}{l}0.1 \text { to } 0.3 \mathrm{~m} \text { thick normal graded } \\
\text { beds commonly with large } \\
\text { wavelength ( } 5 \mathrm{~m}) \text { cross- } \\
\text { stratification. }\end{array}$ & 37 \\
\hline 12 & $\mathrm{~F}$ & $>10$ & $\begin{array}{l}\text { Accessory lithoidal } \\
\text { and essential glassy } \\
\text { vesicular pantell- } \\
\text { erite }\end{array}$ & $\begin{array}{l}\text { Non-welded blocks, } \\
\text { lapilli and ash. }\end{array}$ & $\begin{array}{l}\text { Up to } 5 \mathrm{~m} \text { thick plane parallel } \\
\text { beds with marked normal grading. } \\
\text { Small wavelength (<lm) cross- } \\
\text { bedding in ash-rich layers. }\end{array}$ & 29 \\
\hline 13 & $\mathrm{~F}$ & 80 & Essential pumice & $\begin{array}{l}\text { Incipiently welded } \\
\text { blocks (up to } \mathrm{Im} \text { ) } \\
\text { and lapilii. }\end{array}$ & A single mostly massive unit. & 28 \\
\hline 14 & $\mathrm{~F}$ & 20 & $\begin{array}{l}\text { Accessory lithoidal, } \\
\text { glassy pantellerite } \\
\text { and obsidian }\end{array}$ & $\begin{array}{l}\text { Incipiently welded } \\
\text { lapilli-tuff with } \\
\text { rare blocks up to } \\
0.7 \mathrm{~m} \text { in size. }\end{array}$ & $\begin{array}{l}\text { Very large wavelength }(8-15 \mathrm{~m}) \\
\text { low angle cross-stratification } \\
\text { in otherwise plane non- } \\
\text { parallel bedding. }\end{array}$ & 13 \\
\hline 15 & $\mathbf{F}$ & 45 & $\begin{array}{l}\text { Essential pumice and } \\
\text { accessory 1ithoidal } \\
\text { pantellerite }\end{array}$ & $\begin{array}{l}\text { Incipiently welded } \\
\text { lapilli and ash with } \\
\text { common blocks up to } \\
\text { lm. }\end{array}$ & $\begin{array}{l}0.5 \text { to } 3 \mathrm{~m} \text { thick plane parallel } \\
\text { and non-parallel beds mostly } \\
\text { with norma } 1 \text { grading. }\end{array}$ & 21 \\
\hline 16 & E & 20 & $\begin{array}{l}\text { Accessory lithoidal } \\
\text { and glassy panteli- } \\
\text { erite and absidian }\end{array}$ & $\begin{array}{l}\text { Blocks, lapilli and } \\
\text { ash cemented by } \\
\text { zeolites. }\end{array}$ & $\begin{array}{l}\text { Thick lenticular breccia beds } \\
\text { grading upwards to low angle } \\
\left(1-3^{6}\right) \text { planar cross-bedded } \\
\text { lapilii-tuff. }\end{array}$ & 23 \\
\hline
\end{tabular}

* A = pyroclastic airfall deposits, $F=$ pyroclastic flow deposits, $E=$ epiclastic deposit.
+ particle size classification of Fisher (1961). 


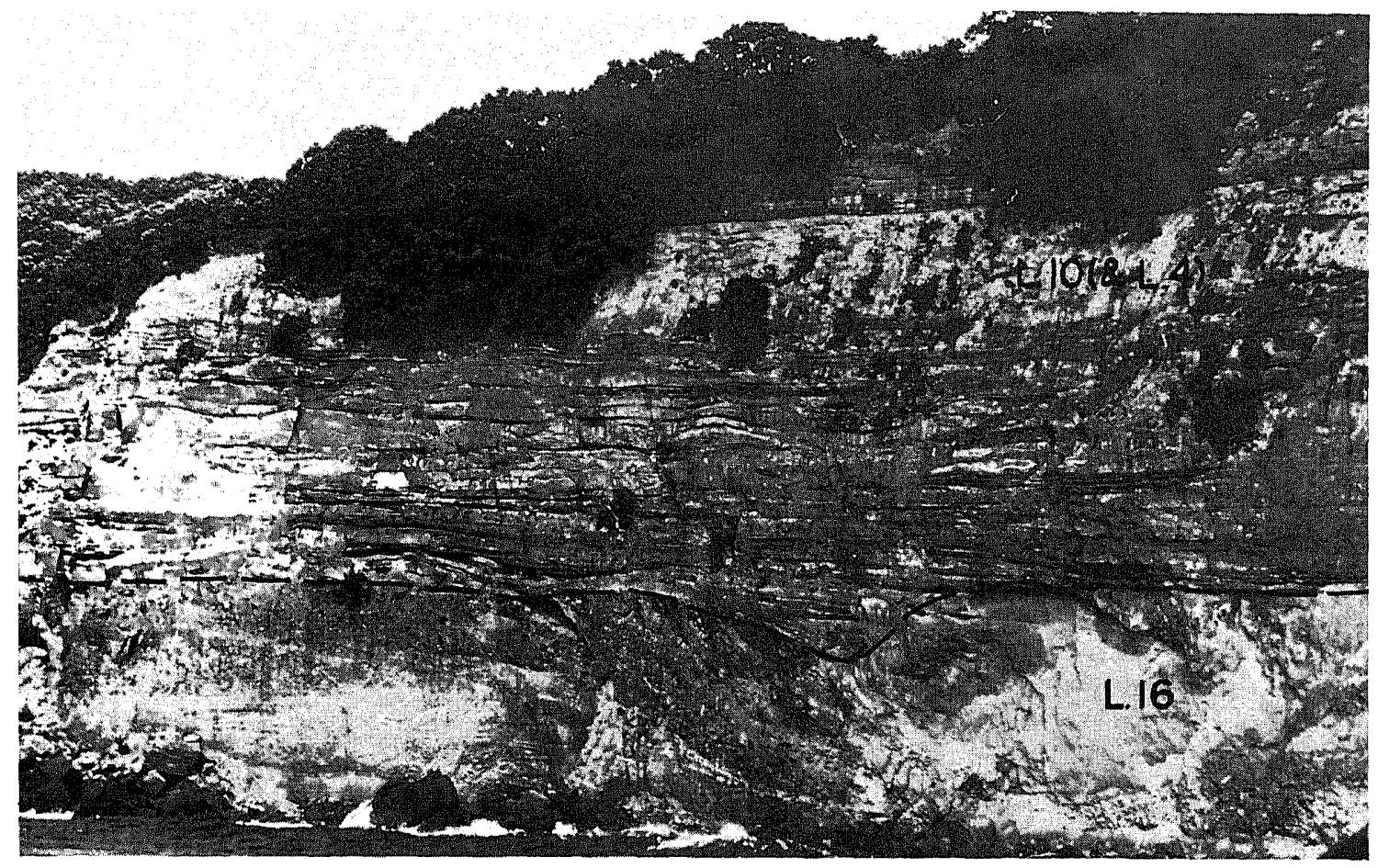

Fig. 4 The cliff at south Taratimi Bay (site 11). A thick sequence of base surge deposits (lithotype 10) and thrn interbedded plinian pumice tephras (lithotype 4) overlie the aggradational surface of the epiclastic deposits (lithotype 16). Note the large chute-and-pool structures and dune structures in lithotype 10, indicating a right to left direction of flow, and the large channel-fill structure in lower right of lithotype $16 . \mathrm{L}=$ lithotype.

the median particle size decreases while sorting increases with increasing distance from the source.

Lithotypes 6 to 15 in Table 1 represent deposits that have originated from pyroclastic flows and their gross characteristics differ significantly from the tephra deposits. The flow deposits are mainly confined to previous topographically low areas, may have either an irregular and indistinct stratification or a well-developed cross bedding, a heterogeneous grainsize both laterally and vertically, and a high matrix content which may cement the deposit. A variety of different pyroclastic flow mechanisms have been recognised, including ignimbrites, nuées ardentes and base surges.

Lithotype 16 is a thick sequence of reworked pyroclastic deposits which according to the definition of Fisher (1961) can be referred to as epiclastic deposits. They constitute Te Ananui and Te Kopua Flats, Te Horo Point, and south Taratimi Bay (Fig. 4). The deposits of lithotype 16 are limited in their extent by the shape of the underlying depositional basin and form irregular fans with the fan apex extending towards the centre of the volcano.

\section{Composition}

\section{Dominant fragment types}

The main types of fragments occurring in Mayor Island pyroclastics are lithoidal (or crystalline) and glassy pantellerite, obsidian (wholly glassy pantellerite which displays conchoidal fracture), pumice, glass shards, accretionary lapilli, and free crystals (phenocrysts and phenocryst fragments).

The pantellerite fragments exhibit the same great variety of colours, textures, and structures as the lava flow rocks (see Bartrum 1926; Marshall 1936; Buck 1978). They are mainly black, grey, green, red, pink, or white, varying from vesicular to amygdaloidal, holocrystalline to hypocrystalline (aphanitic and phaneritic), and some show flow banding with occasional compositional layering.

Obsidian varies in colour from black, green, greenish black, brown to grey and is occasionally vesicular or microlitic, or microporphyritic with anorthoclase, aegirine, and aenigmatite microphenocrysts. 
With only a few exceptions the pantellerite and obsidian fragments have blocky shapes with broken edges which suggests that they are predominantly accessory, derived from pre-existing rocks and thrown out by the eruptions; in the following text they are referred to as lithic fragments.

Fragments of porphyritic olivine basalt and trachybasalt have been collected from a number of airfall and flow lithotypes, and are considered by Rutherford (1978) to represent the basic end of a fractionation sequence which culminated in peralkaline magma.

Pumice generally occurs as subrounded to angular, pale grey to white fragments containing rare anorthoclase phenocrysts. The vesicles vary in size, in thickness of their walls, are commonly attenuated to produce a fibrous texture, and exhibit the 3 textural types described in the Taupo Pumice by Ewart (1963).

Glass shards occur as curved, platy, and pumiceous fragments and occupy the finest size range in all deposits on Mayor Island. They are the dominant fragment type (i.e., $>50 \%$ by volume) only in lithotype 3 . Airfall deposits generally have a lower proportion of platy fragments while flow deposits have a higher proportion of pumiceous shards. In all instances the pumice and glass shards are essential fragments, being derived from the juvenile magma.

Accretionary lapilli are abundant in lithotype 11 and common in lithotype 6, ranging in diameter from $1.5 \mathrm{~mm}$ to $7 \mathrm{~mm}$. They are generally spherical, with structureless ash cores more than one-half the lapilli diameter, surrounded by concentrically layered fine-grained rims, and have formed probably by the agglutination of ash in a moist ash cloud.

\section{Mineral assemblage}

All pyroclastic deposits on Mayor Island contain a percentage of free crystals, especially in the 0.5$0.063 \mathrm{~mm}$ size range. The mineral assemblage is predominantly peralkaline rhyolite in composition and contains, in decreasing order of abundance, anorthoclase, aegirine, aenigmatite, riebeckite, magnetite, ilmenite, biotite, quartz, plagioclase, fayalitic olivine $\left(\mathrm{fo}_{24}\right), \alpha$-cristobalite, tuhualite, and apatite.

\section{Welding and cementation}

Many pyroclastic flow deposits on Mayor Island show some degree of welding, and according to the classification of welding outlined by Smith (1960) the deposits vary from non-welded, through incipiently welded to partially welded. Dense welding is rare and is only recorded locally in lithotype 7 .
The non-welded lithotypes vary from unconsolidated, friable deposits to deposits having a coherency marked by the sticking together of glassy fragments at their points of contact. Thus, although lithotypes $8,9,10$, and 12 are non-welded, the adhesion between fragments allows them to form cliffs in some localities (e.g., Fig. 5). Incipient welding occurs when the glassy fragments begin to deform, and partial welding is marked by further deformation and a noticeable reduction in porosity.

Maximum welding would occur where heat retention in the deposit was greatest and variations in welding would be caused by different rates of heat loss through and across the flow deposit. In any 1 pyroclastic flow unit on Mayor Island the greatest degree of welding typically occurs where the deposit is thickest, with transitions above, below, and laterally.

The airfall deposits are non-welded except where they have been locally baked by heat from an overlying lava flow.

However, while welding is the dominant factor influencing induration of the Mayor Island pyroclastic deposits, cementation of some of the pyroclastic rocks by zeolites, namely heulandite and mordenite, sometimes occurs. Zeolitisation of the deposits is recognisable in the field where the normal greybrown ash or matrix of the deposits has changed to yellow, orange, or less commonly pale green. The origin of the zeolitisation process may be due to former hot-spring activity which caused hydrothermal alteration at extremely shallow depths (cf. Sameshima 1978).

\section{MECHANISMS OF ERUPTION AND EMPLACEMENT}

\section{Pyroclastic airfall mechanisms}

Lithotype 1 (e.g., sites 3, 10, 22, 27, and 37) constitutes tephras which contain a predominance of accessory lithic fragments which are blocky, poorly vesicular, and have rough broken surfaces, which indicates that they were fragments of pre-existing lavas broken from the conduit wall. The small quantity of pumice in these deposits further suggests that the primary magma contributed little fresh magmatic material to the deposit and the repetitive shower bedding characteristic of lithotype 1 indicates that there was a series of eruptive pulses. Therefore, lithotype 1 deposits are probably derived from phreatic or phreatomagmatic eruptions, where the subsurface magma acted only as a heat source for the eruption, and were triggered when waters percolating though the fractured and jointed overlying material were vapourised explosively on contact with the magma. 
Fig. 5 Cliff section at south Omapu Bay (site 3) showing a sequence of pyroclastic airfall (lithotypes 1, 3, and 4) and pyroclastic flow (lithotypes 8,9 , and 10) deposits. Note the welldeveloped low-angle cross bedding in lithotype 10. The paleosol near the base of the sequence is

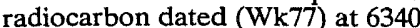
\pm 190 years B.P. $\mathrm{L}=$ lithotype.

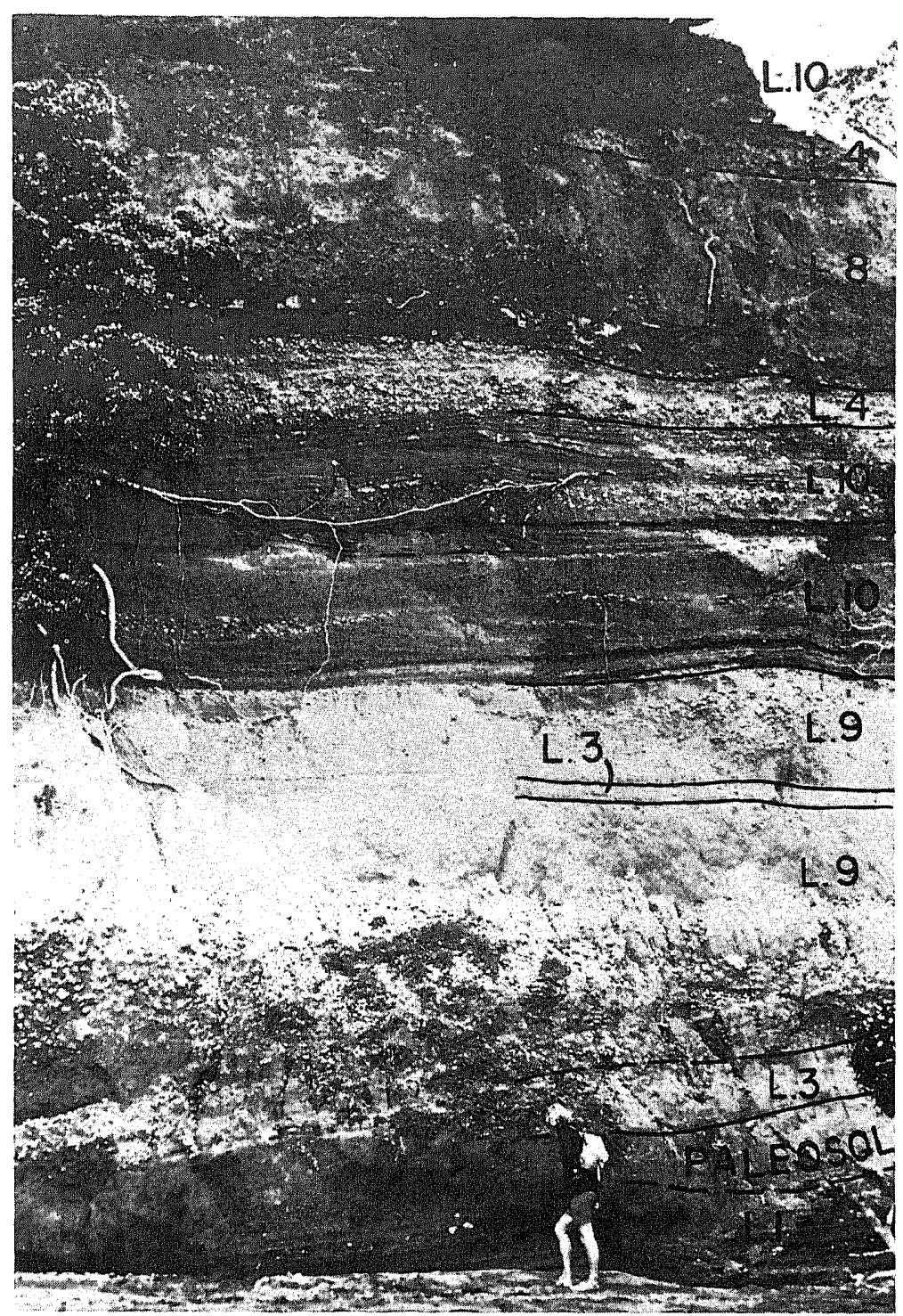

Lithotype 2 (e.g., sites 10-13) appears to be derived by phreatoplinian eruptions (Self \& Sparks 1978) in which large additions of water to a rising magma column modified a normal plinian eruptive style. Lithotype 2 is a well-stratified, fine-grained pumice deposit which suggests that repetitive eruptions were induced when pulses of rising magma came into contact with water. The "wet explosions" greatly increased the fragmentation of the magma and large amounts of water were included in the eruptive cloud. Deposition from this cloud produced a very wet, fine-grained pumice deposit, and the bedding was deformed, rather than destroyed, by the impact and deep penetration of falling blocks. The source of the large volume of water may have been from an early crater lake.

Lithotypes 3, 4, and 5 are deposits which contain predominantly pumice, glass shards, and loose crystals, all of which are juvenile magma fragments.

Lithotype 3 (e.g., sites $3,10,26,27,29$, and 44) is characterised by containing mainly ash-size fragments, and varies in composition from a crystalvitric to a vitric ash. To produce such fine-grained ejecta these eruptions must have been highly 
explosive, causing complete fragmentation of magma. The prior crystalline state of the magma would determine the relative proportions of constituents in the resulting deposit, and glass shards that were originally the septa separating the vesicles and bubbles in the expanded magma froth are generally most abundant. The portions escaping complete disruption survived as lumps of pumice.

Lithotypes 4 and 5 are primary magmatic deposits similar to the plinian pumice-fall deposits noted by Walker \& Croasdale (1970), Booth (1973), and Lirer et al. (1973). According to Walker \& Croasdale (1970), plinian eruptions are continuous gas blast eruptions which eject copious amounts of pumice. The pumice deposits of lithotype 4 (e.g., sites 34 and 35) are typically about $1 \mathrm{~m}$ thick and contain uniformly coarse-grained ejecta over their entire lateral extent on the island. This suggests a sarticularly violent explosion with the eruptive olumn reaching such a height that very wide and Iniform dispersal of the pumice was achieved. Four lifferent types of grading are present in lithotype 4 leposits, varying from normal grading, non-grading, tormal-inverse grading (fine middle) and inverselormal grading (coarse middle), which possibly reflect changes in vigour of the eruption, with the finer sized fragments being derived and deposited during the period of maximum gas release when greatest fragmentation is achieved.

Lithotype 5 (e.g., sites $26-30$ ) is the more typical plinian pumice-fall deposit because of its greater thickness and extent, and its lack of stratification, suggestive of a continuous and consistent release of gas, but at a rate that prevented complete fragmentation. Lithotype 5 is confined to the western side of Mayor Island, probably because a strong easterly wind was blowing during its eruption which dispersed it as far as the eastern side of the North Island.

\section{Pyroclastic flow mechanisms}

Ignimbrite is defined by Sparks et al. (1973) as a pyroclastic rock composed predominantly of vesiculated juvenile material (pumice and glass shards) showing features indicative of a pyroclastic flow origin; there is no inference in the usage of the term either to degree of welding or to the magnitude of the eruption. Their definition further states that features of a flow origin may be recorded in a 3-unit flow sequence. Fisher (1979) has expanded this sequence so that an idealised depositional flow-unit model for ignimbrites now consists of a ground surge unit (layer a), a pyroclastic flow unit (layer b), an ash cloud surge unit (layer c), and a thin, capping tephra fallout or co-ignimbrite ash unit (layer d). The model for ignimbrites proposed by Fisher
(1979) fits closely lithotypes 6-9, except that they sometimes show small variations caused primarily by unusual discharge conditions at their parasitic vent at Panui peak (Buck in press).

Lithotype 6 (e.g., site 38) attains its maximum thickness in the eastern caldera wall where it consists of 6 separate flow units, each comprising layers $a$ and $b$ as described by Fisher (1979). Layer b in each flow unit is consistently $2-3 \mathrm{~m}$ thick, but layer $\mathrm{a}, 1.5 \mathrm{~m}$ thick in the lowest unit, becomes progressively thinner in the upper units. Therefore, the ground surge preceding each ignimbrite flow was initially strong but became gradually weaker with successive eruptions; this sequence may represent the tapping of successively deeper levels in the magma chamber and the escape of magma with progressively lower gas content as the eruption proceeds.

Lithotypes 7, 8, and 9 represent only layer b of ignimbrite flows and each comprises different lithologies (Buck in press). Lithotype 8 (e.g., Otutawaroa Peninsula) is identical to the single flow unit described by Sparks et al. (1973) except that it lacks the ground surge layer. The basal part of layer b consists only of fine-grained matrix material and results from a regime in the pyroclastic flow in which the larger fragments were excluded, probably due to high shear and grain dispersive forces near the base of the flow (Sparks et al. 1973). Above the finegrained layer a thicker unit contains large pumice clasts in its upper parts and lithic fragments showing normal grading towards its lower parts, which implies that the matrix in the moving pyroclastic flow was only slightly expanded and behaved as a homogeneous fluid phase in which the larger pumice clasts literally floated to the top while the denser lithic clasts sank.

Unlike lithotype 8, layer b in lithotype 7 (e.g., site 37) appears simply as a normally graded, lithic fragment rich unit, where large pumice fragments are absent. However, inverse grading of coarser fragments in lithotype 9 (e.g., site 3) makes the finegrained layer appear very much thicker than normal and there is a concentration of both lithic and pumice fragments in the upper parts of layer $b$ suggesting that the matrix during flow was somewhat cooler than those described above and therefore poorly expanded. The denser moving cloud would probably set up highly concentrated grain dispersive forces similar to those described in subaqueous debris flows (Fisher 1971) which would "buoy up" the larger heavy lithic fragments.

Base surge, ring-shaped density flow from the base of a vertical explosion column (Moore 1967), is the eruption mechanism suggested for lithotypes 10 and 11. They are distinct from the ground surge deposits associated with the ignimbrites described 
above in that they are generally coarser grained, thicker deposits, and are not associated with an overlying ignimbrite unit. The base surge deposits are thickest closest to the source or where the main load of a surge cloud has been confined and funnelled through pre-existing valleys (Fig. 4). With increasing distance from the source and where topographic restrictions are absent the deposits thin out and become better sorted (Fig. 5).

Initial velocities of base surges may exceed $50 \mathrm{~m} / \mathrm{s}$ (Moore 1967) so that deposition of material from the ejecta-laden cloud occurs in very high flow regimes, progressively diminishing with distance from the source. Five types of upper flow regime, dune-like bedforms have been described from base surge deposits by Schmincke et al. (1973) and very similar features are observed in lithotypes 10 and 11 . For example, chute and pool structures of the uppermost upper flow regime occur at several localities on or near to the caldera walls (e.g., sites 11 , and 34 in lithotype 10 , and site 37 in lithotype 11) and consequently close to or right at the source vent, whereas $1.5 \mathrm{~km}$ from the vent at Opo and Omapu Bays lower upper flow regime dune, antidune, and plane bed structures occur.

Most base surges have been recorded from phreatic explosions (e.g., Waters \& Fisher 1971; Nairn et al. 1979) and a similar origin is suggested for the base surges on Mayor Island because their deposits are comprised predominantly of accessory glassy lithic fragments, lack essential pumice, and show plastic deformation of beds indicating that they were once wet and coherent.

Lithotype 12 on Mayor Island shows many features in common with the Peléan nuée ardente deposits described by Murai (1961) and Williams \& McBirney (1969) in that it is laterally confined to a radial paleovalley (at Otiora Bay, sites 29 and 30) and is composed of coarse, chaotic, block-rich beds in the lower sections, emplaced by the basal avalanche of a nuee ardente, and thin ash-rich overlying beds, emplaced by the overriding expanding gas cloud whose velocity was such that some antidune cross bedding was produced.

Lithotype 13 is an extremely thick $(80 \mathrm{~m})$ flow unit confined to the western side of the main cone, exposed at Mawai Bay, sites 27 and 28. It is composed predominantly of incipiently welded, vesicular ( $>40 \%$ vesicles) pumice blocks, underlain by thin, vitric lithotype 3 tephra units (Fig. 2, Oira Bay section). The tephra beds are presumably the result of the initial explosive removal of a confining crust in the vent, followed by high gas pressure eruptions of vitric ashes. As the gas pressure diminished, huge volumes of pumice were discharged as a single "glowing avalanche". The extremely vesicular pumice indicates the primary magma had a high volatile content and small amounts trapped within vesicles would have escaped during flowage, buoying up the huge volume of material, but allowing only a short distance of travel. Consequently, the flow would have moved fluently en masse as an avalanche emplacing a thick, unstratified pumice unit.

Lithotypes 14 and 15 are both relatively thick deposits (up to $45 \mathrm{~m}$ for lithotype 15), are essentially non-welded, but have prominent bedding throughout. Eroded remnants of lithotype 14 are confined to vertical-walled paleovalleys in central Taratimi Bay. It contains a predominance of lithic lapilli and ash fragments suggesting a phreatic mechanism of eruption, and its very large wavelength $(8-15 \mathrm{~m})$ cross bedding implies flow conditions in the uppermost lower flow regime. The relative slowness of the flows was possibly promoted by poorly expanded phreatic eruption clouds, directed along deep entrenched valleys, where deposition occurred continuously in a grain by grain, layer by layer fashion, from a relatively cool flowing unit which prevented any welding of the deposit.

Lithotype 15 contains abundant vitric fragments indicating the eruptions were magmatic in character and has well-developed plane parallel bedding with occasional antidune cross bedding, denoting layer by layer deposition in the lowest upper flow regime. At Orongatea Bay (Fig. 6), lithotype 15 occupies an old steep-sided valley where the deposits occur in several well-bedded units with each unit having a different bed attitude. Some units have beds which exceed the angle of repose and occasionally are steeply truncated against underlying units. These pyroclastic flow eruptions appear to have been directed to the south from a vent in the north, possibly situated in Orongatea Bay where presently there is a hot water spring (Brothers 1957). The south-moving flow encountered a near-vertical insurmountable lava cliff, now exposed by erosion, which caused the flow to plaster against the cliff, depositing steeply north-dipping beds, but also deflected it towards the steep-sided valley. The deflected parts of the flow deposited layers at various attitudes until an unhindered trajectory was achieved, resulting in horizontal bedding.

\section{Epiclastic mechanisms}

Brothers (1957) first interpreted the epiclastic deposits now referred to as lithotype 16 as subaqueous sediments, deposited in a marine environment during a period of higher sealevel. However, lithotype 16 was deposited within the last 6340 years (see later), during which time there has been little change in sealevel (Schofield 1973, 1975) and therefore it must be of subaerial origin. Furthermore, lithotype 16 is a fining upwards 


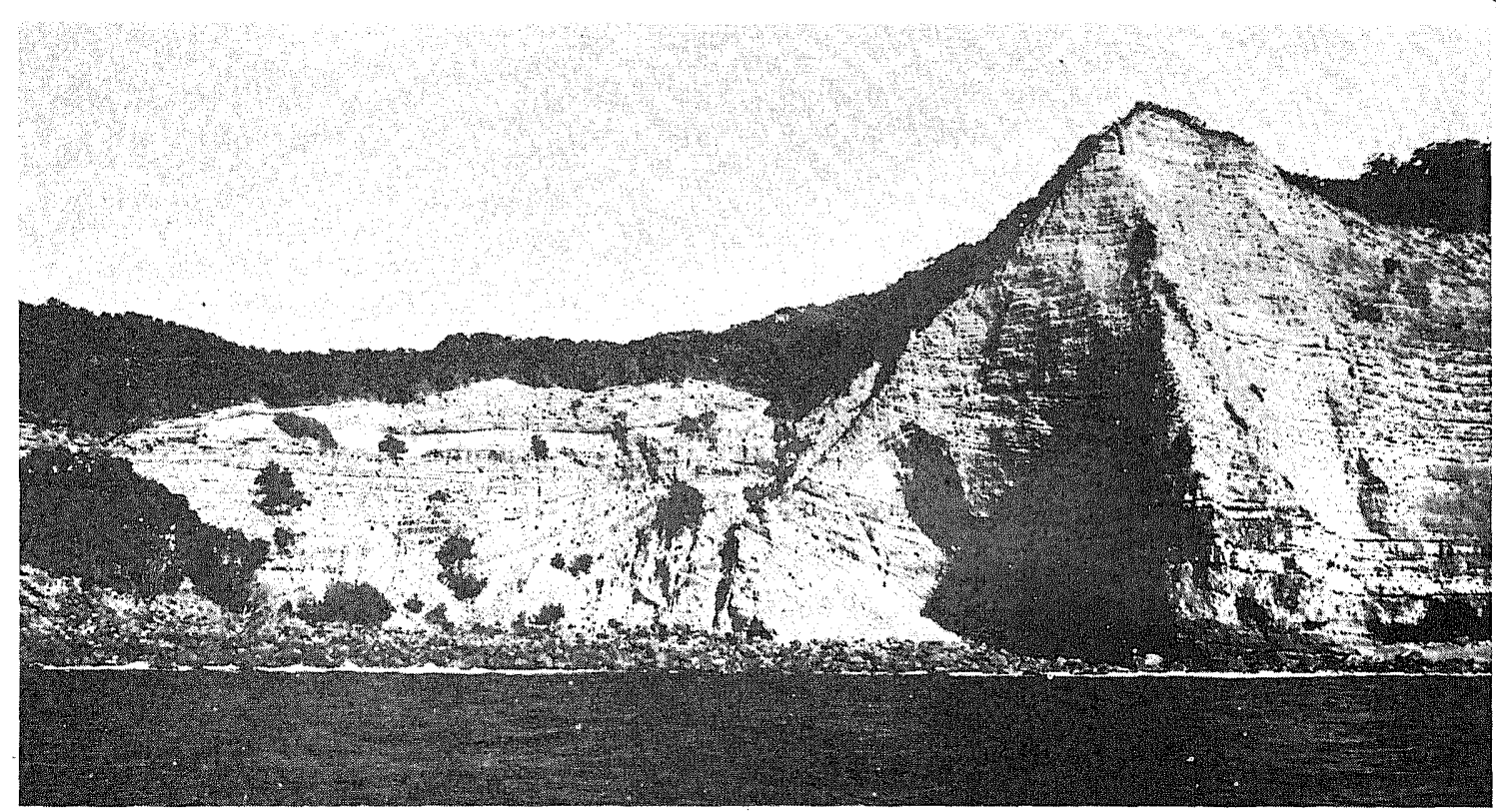

Fig. 6 Thick pumiceous pyroclastic flow deposits (lithotype 15) at east Orongatea Bay. Note the truncation of wellbedded units (lower central section of cliff face) that were deposited at various attitudes from a flow that was deflected in many directions by a nearby old cliff line. Highest point is approximately $45 \mathrm{~m}$.

sequence from coarse, lithic block rich, lensoid strata to cross-bedded and parallel-bedded sands, which is almost identical to the braided river channel-fill sequence described by Reineck \& Singh (1973). Thus lithotype 16 was presumably produced by high energy braided floods that were confined to large valley systems that are now occupied, for example, by Te Ananui and Te Kopua Flats.

However, a problem arises as to the origin of the large volumes of water necessary to transport gravels and to deposit fluvial beds up to $20 \mathrm{~m}$ thick. Normal climatic precipitation, rains from times of increased storminess during eruptions, water and steam from hot springs and geysers, and releases of juvenile water during eruptions, all appear to be insufficient to produce such large volumes of runoff. One possibility is that a large lake once occupied the caldera and that paroxysmal eruptions, for example, the phreatic base surge eruptions that deposited lithotypes 10 and 11 , produced large waves of water like those produced in recent phreatic eruptions in Ruapehu Crater Lake (Nairn et al. 1979), that sloughed over low notches in the caldera wall. Such deluges would produce short term, short reach, large volume braided floods that stripped the soft pyroclastic surface materials in the valleys to bare rock, depositing them as large aprons forming $\mathrm{Te}$ Ananui and Te Kopua Flats, and possibly draining the lake. Such an ancestral lake would certainly have been displaced, and evidence for its existence buried, during subsequent eruptions.

\section{VOLCANIC HISTORY}

From this study of the pyroclastic deposits and the recognition of a variety of distinct lithotypes and eruptive mechanisms in the Oira Pyroclastite, we are now able to refine the earlier volcanic history of Mayor Island described by Brothers (1957). We have also identified the mainland-derived Rotoehu and possibly Rotoma Ashes (Fig. 2 and 3), intercalated between lavas and pyroclastics on Mayor Island, and this, combined with 2 new radiocarbon dates from the Oira Pyroclastite, effectively provides 4 time planes from which a stratigraphic record can be erected. However, the relative chronology of volcanic events presented here is an interpretative, and therefore tentative one. It is undoubtedly an oversimplification of the actual volcanic processes and events because of the lack of lateral continuity and hence correlation of the pyroclastic deposits between exposed sections. Consequently, the allotment of certain pyroclastic units to a particular stratigraphic phase in the 
volcanic history is sometimes difficult, especially since the deposits are so close to their source and variable both laterally and vertically, and some, like the pyroclastic flows, are very locally confined.

Eight phases of volcanic activity have been recognised, and are summarised in a diagrammatic sequence of events in Fig. 7 and 8.

1. Initial volcanism on Mayor Island must have commenced prior to the deposition of the Rotoehu Ash, dated at about 42000 years, which has been identified intercalated between lava flows on the western side of the island (unit between lava flows $C$ and D, Opoupoto Bay section, Fig. 3). The Rotoehu Ash here occurs as a series of ash beds, normally graded, totalling $1.4 \mathrm{~m}$ thick, and has been identified from the presence of abundant cummingtonite (constitutes $>80 \%$ of the ferromagnesian assemblage), common hypersthene and hornblende, and minor augite and biotite, that is, a calcalkaline mineral assemblage that is quite incompatible with the peralkaline rhyolite lavas and pyroclastics derived from Mayor Island.

However, approximately three-quarters of the volume of Mayor Island volcano lies below sealevel, which suggests that initial submarine volcanic events commenced much earlier than 42000 years ago, probably sometime during the middle to late Pleistocene. This early volcanism progressively constructed the main cone, and high cliff exposures along the west coast and in the caldera wall show it to be built up by a series of extensive lava flows with obsidian selvedges and intercalated thin airfall ashes (lithotypes 1 and 3).

The construction of the main cone must have been a slow process because some lavas and pyroclastics, including the Rotoehu Ash, have paleosols developed on them. The stratigraphic horizon along which the Rotoehu Ash occurs marks a particularly long quiescent period because it and the underlying lava flow is totally eroded in parts so that the succeeding lava flow clearly truncates both Rotoehu Ash and the preceding flows. Probably also during this period of quiescence, the island, which had extended as far to the north as Tokopapa Island and to the east as Tuhua Reef, had eroded back to almost its present circumference.

2. Main cone building continued after 42000 years with the eruption of further lavas, each preceded by thin airfall ashes, and accompanied by localised ignimbrite flows. The ignimbrite flow of lithotype 14 at Taratimi Bay was possibly erupted at about this time as it overlies some older lavas of the main cone.

3. After a period of quiescence, shown by further erosion and formation of a paleosol on these post42000 -year lavas and pyroclastics, there was a phase of more violent explosive volcanism. This phase of volcanism involved a series of large-magnitude eruptions which initially produced welded and nonwelded ignimbrites (lithotypes 6 and 7 at sites 38 and 37 ), followed by a voluminous glowing pumice avalanche that moved down the paleovalleys on the northwestern flanks of the main cone (lithotype 13 at Oira Bay), and culminated in a succession of phreatic base surge eruptions (lithotype 11 at site 37). These eruptions expelled considerable volumes of magmatic material and may have triggered the development of the ring fracture that was to later form the caldera.

This phase is considered to have occurred immediately prior to the deposition of the Rotoma Ash derived from the Okataina Volcanic Centre, and dated at approximately 9000 years (Cole \& Nairn 1975). This ash has been tentatively identified at 3 localities on Mayor Island: (1) as a fine ash overlying lithotype 13 at Oira Bay; (2) as a fine ash in a well-developed paleosol near beach level at south Omapu Bay; and (3) as an airfail ash near the top of the pyroclastic sequence exposed at site 37 in the calciera wall behind Te Paritu Lake. At the last site it occurs in a poorly developed paleosol underlying a pumice lapilli layer containing charred logs newly radiocarbon dated (Wk105*) at $8000 \pm 70$ years B.P. (N54/765069). Heavy mineral analysis of this tephra at these 3 localities shows it contains abundant hypersthene with progressively lesser amounts of hornblende, cummingtonite and augite, which suggests it may correlate with the Rotoma Ash. At the 2 sites of south Omapu Bay (site 3) and in the caldera wall where it occurs in a paleosol, there has been some mixing of the deposit, presumably by soil-forming processes, with adjacent Mayor Island-derived peralkaline pyroclastics, since aegirine, aenigmatite and riebeckite are also present.

4. The formation of a paleosol on the Rotoma Ash marks another quiescent period of approximately a thousand years before a further volcanic episode ensued, characterised by several violent phreatoplinian eruptions. These eruptions probably incorporated large volumes of water high into the ash column and resulted initially in the deposition of an extensive mantle of finely comminuted wet pumice and glass that lies unconformably on the earlier deposits. Probably all vegetation was destroyed and $30 \mathrm{~cm}$ diameter trees were blasted, charred and broken off to point away from the vent. The new radiocarbon date (Wk105, above) of tree samples at site 37 places this phase of activity at $8000 \pm 70$ years B.P. and most likely matches with the $8390 \pm 135$

*Numbers prefixed Wk refer to the University of Waikato Radiocarbon Dating Laboratory number. Conventional radiocarbon age, based on Libby half life of 5568 years. 


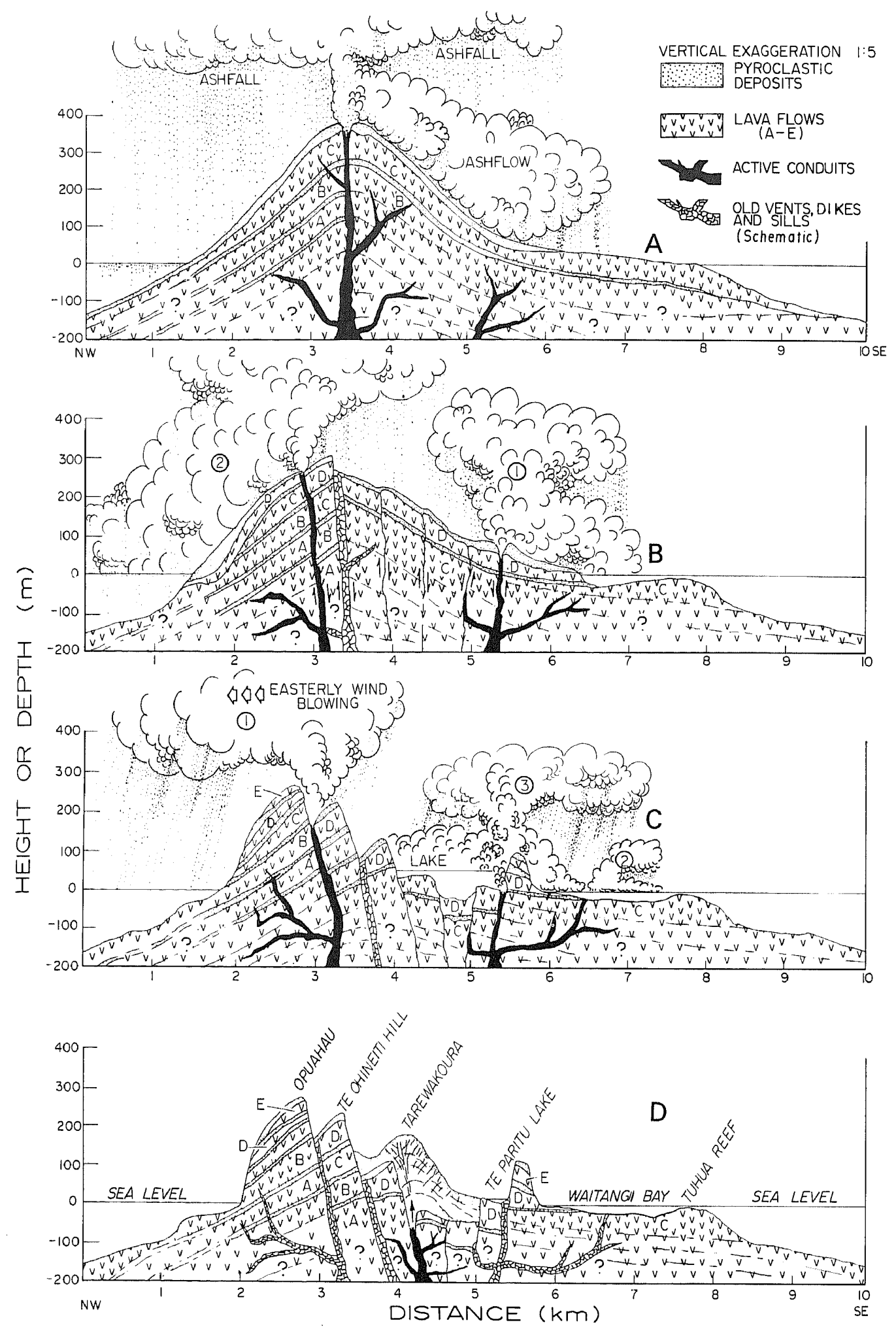




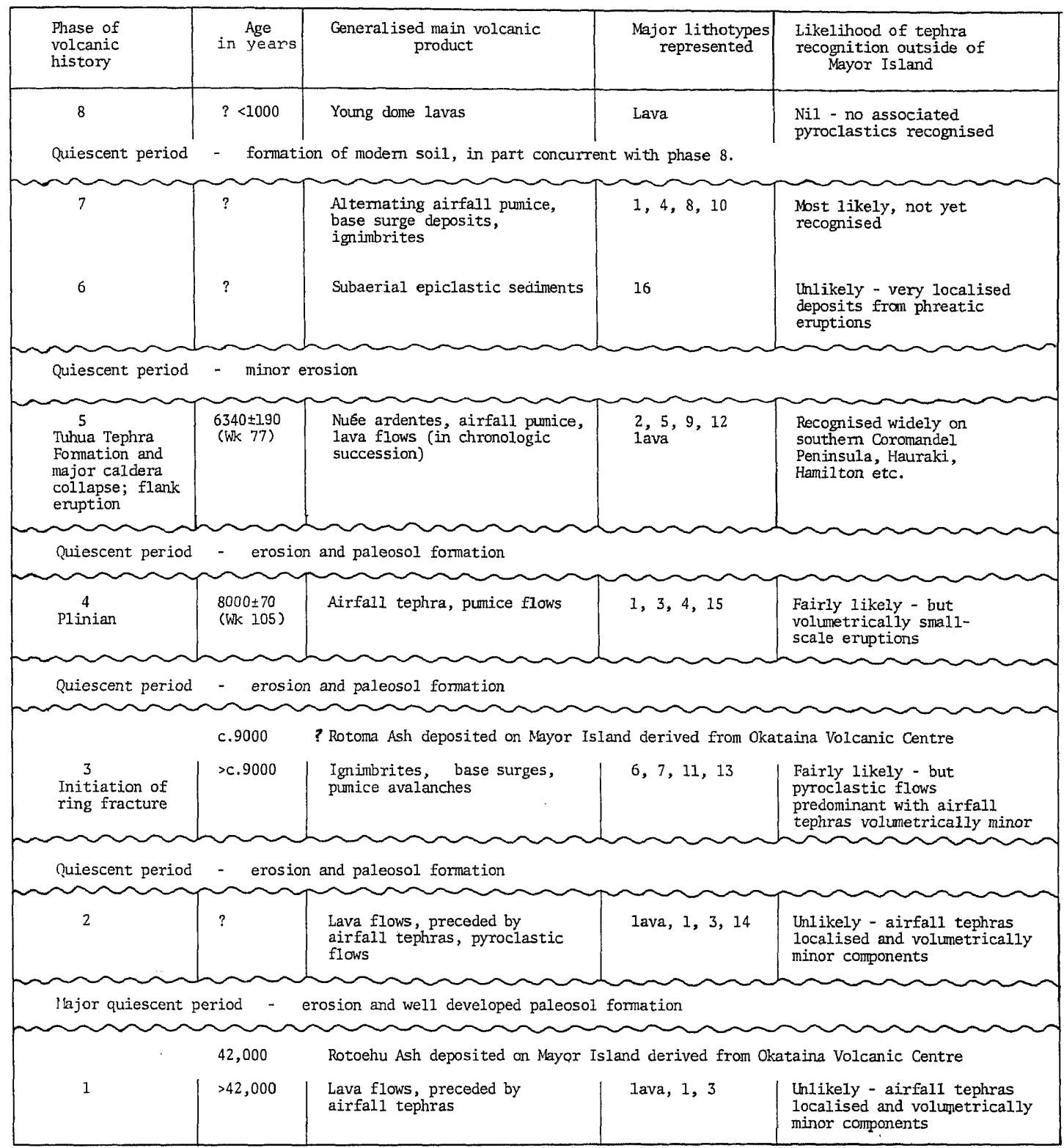

Fig. 8 Summary of the volcanic history of Mayor Island.

Fig. 7 (opposite) A diagrammatic representation of the sequence of volcanic activity on Mayor Island.

A Pre-42 000 years (phase 1); construction of main cone by thick lava flows, thin tephras and localised ignimbrites. Subsequent quiescence and extensive erosion. B 42000 years to 8000 years ago (phases 2-4); further thick lava flows cover parts of the eroded main cone. Later, ignimbrites and base surge (1) and a large glowing avalanche (2) escape from vents on a developing ring fracture. Intermittent quiescence and paleosol formation. C 8000 years to about 1000 years ago (phases 5-7); voluminous plinian pumice eruptions (1), accompanied by flank vent ignimbrites (2) 6340 years ago, cause large-scale caldera collapse. Succeeding phreatic base surges (3) erupt through a caldera lake accompanied by intermittent plinian activity. D Post-1000 years (phase 8); exogenous growth of lava dome on caldera floor and soil development elsewhere. Present period is quiescent. 
years B.P. date (NZ370) previously recorded by Grant-Taylor \& Rafter (1962) for wood samples collected at what appears from the radiocarbon records to be the same locality.

This phase may also have seen a change from eruptions at a central vent to eruptions located possibly near Te Paritu Lake along a developing ring fracture which was to lead to the formation of the caldera, and 2 other flank eruptions at Orongatea Bay (which produced lithotype 15) and Otutawaroa Peninsula. At Otutawaroa Peninsula, seen in cliff sections on the southern side of Opo Bay, a parasitic cone was constructed by a series of thick coarsegrained ash and lapilli beds containing blocks up to 2 $\mathrm{m}$ across and dipping at up to $28^{\circ}$.

5. During a subsequent period of inactivity, shown by further erosion and the development of clay-rich soils, magmatic gases accumulated at high pressures. These ultimately gave rise to a major episode of volcanic activity, dated (Wk77) at $6340 \pm 190$ years B.P. (see below). In the initial stages, a new vent (possibly situated near Te Kukuta) was cleared and produced nuee ardente block and ash flows which moved down paleovalleys to Oira and Otiora Bays (lithotype 12). Gas pressures in the magma increased until there was a violent and voluminous plinian pumice eruption which distributed pumice blocks and lapilli in a mantle over Mayor Island. This eruption was spread by strong easterly winds as far as southern Coromandel Peninsula, eastern Bay of Plenty, and the Hamilton district. It produced the Tuhua Tephra (named by Lowe et al. 1980; defined by Hogg \& McCraw in press) on the Coromandel Peninsula and is represented by the nonstratified lithotype 5 which is confined mostly to the western side and is the thickest single airfall tephra unit on Mayor Island.

Contemporaneous with the plinian eruptions, further activity occurred from the Opo Bay parasitic vent where poorly expanded eruption columns collapsed into poorly inflated ignimbrite flows (Buck in press) and the deposits (lithotype 9 at Omapu Bay ) began construction of Otutawaroa Peninsula. Large additions of water to the rising magma, possibly via a series of faults and ring fractures in the developing caldera, then caused several phreatoplinian eruptions and the deposition of the well-stratified lithotype 2 exposed mainly on the eastern side of Mayor Island. Finally, following the escape of the upper gas-rich levels of the magma chamber, the nature of eruptions changed again, to a quieter effusive outpouring of blocky rhyolite lava flows.

These voluminous pyroclastic eruptions caused large-scale collapse of the upper central parts of the main cone to form the present caldera. Intra-caldera blocks collapsed along north to northeast-trending faults within the ring fault.
The new radiocarbon date (Wk77) of $6340 \pm 190$ years B.P. (N54/751052) obtained from charcoal logs in the lowest unit of the ignimbrite flows at south Omapu Bay documents the time of this whole phase of volcanic activity and formation of the caldera. It is consistent with the dates recorded for the Tuhua Tephra determined by Lowe et al. (1980) in the Hamilton district as $6210 \pm 70$ years B.P. (Wk214) and by Hogg \& McCraw (in press) in the Hauraki peat swamp as $6280 \pm 70$ years B.P. (Wk106).

6. Following the formation of the caldera it seems most likely that the caldera was filled by a lake. Stratigraphically overlying the variety of volcanic products of the previous phase of volcanic activity is a sequence of epiclastic deposits (lithotype 16), with alluvial sedimentary structures which we consider required large volumes of water during their formation. We have not observed lake sediments within the caldera, but these, if once present, were probably obliterated or covered by deposits of subsequent eruptions. We suggest that paroxysmal phreatomagmatic eruptions occurred, expelling large volumes of water in great surges from the postulated anicestral caldera lake. The surges swept over the caldera rim to form high-energy, shortreach braided floods down radial gullies in the maiil cone. They deposited pyroclastic debris in a series of 20-m-thick alluvial fans which built up to form the aggradational surface exposed in the cliffs at $\mathrm{Te}$ Ananui Flat, Te Kopua Flat, and other extensive deposits on the eastern ccastline from $\mathrm{Te}$ Horo Point to Taratimi Bay (Fig. 4).

This phase of activity occurred some time after the Tuhua Tephra phase, because the caldera lake would have taken considerable time to fill. This period of inactivity is marked by the erosion surface on lithotype 2 (e.g., at Taratimi Bay, site 13). The small channels, truncation of beds, and irregularities on the aggradational surface of the epiclastic deposits on the eastern side of the island suggest minor erosion into this surface by waning streams with possibly little time before phase 7 .

7. With further lowering of the caldera lake level, the phreatic and phreatomagmatic eruptions continued, but could no longer cause surges of water to overflow the steep-sided caldera. These eruptions produced the youngest sequence of pyroclastic deposits recognised on Mayor Island. The sequence consists of a series of thin base surge deposits with occasional intercalated airfall pumice (lithotype 10 and 4 respectively). The best exposures of this sequence occur at Ruawaipiro Pass (site 34 in Fig. 2 ), sites 43 and 44 , and at numerous localities in the stratigraphically uppermost sections stretching from Otiora Bay in the southwest to Taratimi Bay on the eastern coast. Total thicknesses exceed $30 \mathrm{~m}$ in some 
sections such as Taratimi Bay (Fig. 4) and up to $10 \mathrm{~m}$ at sites 34,43 , and 44 . Phase 7 was concluded by the eruption of a thin ignimbrite flow (lithotype 8 , Fig. 5) and a base surge deposit that is rich in juvenile pumice suggesting that the caldera lake was not present in the later stages of this phase.

Since this volcanic period, the modern soil has developed on the lavas and pyroclastics covering the main cone.

8. The final phase of volcanism on Mayor Island was the eruption of an exogenous rhyolite dome from a central vent onto the fault-stepped floor of the caldera, possibly sited along the Tarewakoura Fault. The lavas gradually covered most of the caldera floor, with only the highest fault block within the caldera and the region of the present small lakes remaining uncovered. The block lavas flanking the dome have a characteristic lobate form with steep margins and are described morphologically in detail and in a choronologically determined sequence by Brothers (1957). The discharge of the young dome probably completely emptied the postulated ancestral lake.

The actual date of eruption of the young dome is unknown, although it must be a very young feature, possibly less than 1000 years, indicated by the very poor soil development on its rough blocky surface (MicCraw \& Whitton 1971), the much smaller size of the pohutukawa trees on the dome compared with those on the flanks of the main cone, and the complete absence of any covering pyroclastic deposits.

The young dome has acted as a large catchment area and surface drainage has filled the hollow between the lavas of the dome and the caldera wall to form Te Paritu and Aroarotamaline Lakes.

\section{DISCUSSION}

Mayor Island has a complex history of repeated and intermittent volcanism characterised by highly explosive pyroclastic eruptions and outpourings of rhyolite lava that have continued since its subaerial emergence sometime prior to 42000 years ago, right up to the eruption of the young dome lavas. The very young age deduced for the young dome lavas, possibly within the last 1000 years, suggests that Mayor Island must be regarded as still active and a potentially dangerous rhyolite valcano, even though at present it is undergoing one of its several quiescent periods.

Since the subaerial emergence of Mayor Island volcano, the overall history of events also suggests that the relative explosivity has increased with time. The earliest events in the volcanic record show a general sequence of extrusions of lava flows each preceded by volumetrically small-scale tephra eruptions, whereas the later Holocene events, with the exception of the young dome lavas, are characterised by volumetrically larger explosive pyroclastic eruptions with only minor associated lava flows. Furthermore, in some events, the pattern of eruptions appears to have commenced with a violent plinian convective eruption column, followed in turn by a series of pyroclastic flows (sometimes formed from collapse of the column), and culminated in effusion of lava.

Only 1 tephra derived from Mayor Island has been positively recognised on the mainland of the North Island, that is, the Tuhua Tephra of Hogg \& McCraw (in press) and Lowe et al. (1980). This tephra was distributed as far as the Hamilton region, at least $110 \mathrm{~km}$ from the source, and it seems surprising that onily 1 volcanic event in Mayor Island's history has been discovered. The last column of Fig. 8 lists the possible likelihood of recognising each of the volcanic phases outside of Mayor Island itself, possibly in the Bay of Plenty region or in offshore drill cores. Phase 3 , dated at just older than the age of the Rotoma Ash (c. 9000 years), phase 4 dated at 8000 years old, and especially phase 7 of unknown age but much less than 6340 years old, are the most iikely volcanic events which may be recognised in the future. The highly characteristic pantelleritic mineral assemblage of aegirine, anorthoclase, aenigmatite, riebeckite, \pm fayalitic olivine, \pm tuhualite in the Mayor Island-derived tephras and their compositional uniqueness to the whole Quaternary volcanism of the North Island, would make them distinctive and easy to identify.

A detailed mineralogicai and geochemical study of the pyroclastic deposits, and also the lava flows, remains to be done. This may provide a basis for fingerprinting individual pyroclastic and lava flow units and concribute further to the volcanic history of Mayor Island volcano.

\section{ACKNOWLEDGMENTS}

We would like to thank the Tauranga Big Game Fishing Club and the Mayor Island Board of Trustees for their cooperation in the course of this work and the use of their facilities on Mayor Island; also the University Grants analytical equipment, and the University of Waikato Radiocarbon Dating Laboratory for ${ }^{14} \mathrm{C}$ age determinations.

\section{REFERENCES}

Adams, R. D.; Ware, D. E. 1977: Subcrustal earthquakes beneath New Zealand; locations determined with a laterally inhomogeneous velocity model. New Zealand journal of geology and geophysics 20 : $59-84$. 
Bailey, D. K.; MacDonald, G. 1976: A fluorine/chlorine discriminant between oceanic and continental peralkaline magmatism (Abstract). Mineralogical Society bulletin $30: 3-4$.

Bartrum, J. A. 1926: The pantelleritic rocks of Mayor Island; Bay of Plenty, New Zealand. New Zealand journal of science and technology $8: 214-223$.

Booth, B. 1973: The Granadilla pumice deposit of Southern Tenerife, Canary Islands. Proceedings of the Geological Association 84: 353-370.

Brothers, R. N. 1957: The volcanic domes of Mayor Island, New Zealand. Transactions of the Royal Society of New Zealand 84: 549-560.

Buck, M. D. 1978: Pyroclastic deposits on Mayor Island, Bay of Plenty, New Zealand. Unpublished M.Sc thesis lodged in the Library, University of Waikato, Hamilton, New Zealand.

(in press): Peralkaline ignimbrite sequences on Mayor Island, New Zealand: Additions to the idealised model for pyroclastic flows. In: Self, $\mathrm{S}$.; Sparks, R. S. J. ed. Tephra studies. NATO Advance Studies Institute, series C. Reidel Netherlands, pp. 337-346.

Cole, J. W. 1978: Tectonic setting of Mayor Island (Note). New Zealand journal of geology and geophysics 21 : 645-647.

Cole, J. W.; Nairn, I. A. 1975: Catalogue of the active volcanoes of the World including solfatara fields. Part XXII New Zealand. Rome, International Association of Volcanology and Chemistry of the Earth's Interior. $156 \mathrm{p}$.

Cotton, C. A. 1941: Some volcanic landforms in New Zealand. Journal of geomorphology $4: 297-306$.

Ewart, A. 1963: Petrology and petrogenesis of the Quaternary pumice ash in the Taupo area, New Zealand. Journal of petrology $4: 392-431$.

1965: Mayor Island. In: Thompson, B. N.; Kermode, L. O. ed. New Zealand volcanology, Northland-Coromandel-Auckland. DSIR information series $49: 70-80$.

Ewart, A.; Taylor, S. R.; Capp, S. R. 1968: Geochemistry of pantellerites of Mayor Island, New Zealand. Contributions to mineralogy and petrology 17: $116-140$.

Fisher, R. V. 1961: Proposed classification of volcaniclastic sediments and rocks. Geological Society of America bulletin 72 : 1409 - 1414 .

1971: Features of coarse grained, high concentration fluids and their deposits. Journal of sedimentary petrology 41 : 916-927.

1979: Models for pyroclastic surges and pyroclastic flows. Journal of volcanology and geothermal research $6: 305-318$.

Grant-Taylor, T. L.; Rafter, T. A. 1962: New Zealand radiocarbon age measurements-5. New Zealand journal of geology and geophysics 5 : 331-359.

Hogg, A. G.; McCraw, J. D. (in press): Late Quaternary tephras of Coromandel Peninsula, North Island, New Zealand: The Whangamata Ash. New Zealand journal of geology and geophysics.

Lirer, L.; Pescatore, T.; Booth, B.; Walker, G. P. L. 1973: Two plinian pumice fall deposits from Somma-Vesuvius, Italy. Gealogical Society of America bulletin 84: 759-772.
Lowe, D. J.; Hogg, A. G.; Green, J. D.; Boubée, J. A. T. 1980: Stratigraphy and chronology of late Quaternary tephras in Lake Maratoto, Hamilion, New Zealand. New Zealand journal of geology and geophysics $23: 481-485$

MacDonald, R. 1974: Nomenclature and petrochemistry of the peralkaline oversaturated extrusive rocks. Bulletin volcanologique $38: 498-516$.

Marshall, P. 1936: Geology of Mayor Island. Transactions of the Royal Society of New Zealand $66: 337-345$.

McCraw, J. D.; Whitton, J. S. 1971: Soils of Mayor Island, Bay of Plenty, New Zealand. New Zealand journal of science 14: 1009-1025.

Moore, J. G. 1967: Base-surge in recent volcanic eruptions. Bulletin volcanologique $30: 337-363$.

Murai, I. 1961: A study of the textural characteristics of pyroclastic flow deposits in Japan. Tokyo University Earthquake Research Institute bulletin 39: $133-248$

Nairn, I. A.; Wood, C. P.; Hewson, C. A. Y. 1979: Phreatic eruptions of Ruapehu: April 1975: New Zealand joumal of geology and geophysics 22 : $155-173$.

Nicholls, J.; Carmichael, I. S. E. 1969: Peralkaline acid liquids- a petrolgocial study. Contributions to mineralogy and petrology-20: 268-294.

Reineck, H. E.; Singh, I. B. 1973: Depositional sedimentary environments. Berlin, Springer-Verlag, 439 p.

Rutherford, N. F. 1978: A comment on the source of Mayor Island pantellerite magma. New Zealand journal of geology and geophysics 21: 449-453.

Sameshima, T. 1978: Zeolites in tuff beds of the Miocene Waitemata Group, Auckland Province, New Zealand. In: Sand, L. B.; Mumpton, F. A. ed. Natural zeolites: Occurrence, properties, use. Oxford, Pergamon Press.

Schmincke, H-U; Fisher, R. V.; Waters, A. C. 1973: Antidune and chute and pool structures of the Laacher Sea area, Germany. Sedimentology 20: $553-574$.

Schofield, J. C. 1973: Post-glacial sea levels of Northland and Auckland. New Zealand journal of geology and geophysics 16 : $359-366$

1975: Sea-level fluctuations cause periodic, postglacial progradation, South Kaipara Barrier, North Island. New Zealand journal of geology and geophysics $18: 295-316$

Self, S.; Sparks, R. S. J. 1978: Charactertistics of widespread pyroclastic deposits formed by the interaction of silicic magma and water. Bulletin volcanologique 41 : $196-212$.

Smith, R. L. 1960: Zones and zonal variations in welded ash flows. United States Geological Survey professional paper 354-F: $149-159$.

Smith, I. E. M.; Chappell, B. W.; Ward, G. K.; Freeman, R. S. 1977: Peralkaline rhyolites associated with andesitic arcs of the Southwest Pacific. Earth and planetary science letters 37: 230-236.

Sparks, R. S. J.; Self, S.; Walker, G. P. L. 1973: Products of ignimbrite eruptions. Geology $1: 115-118$.

Thomson, J. A. 1926: Geological notes on Mayor Island. New Zealand journal of science and technology 8 : $210-214$. 
Walker, G. P. L.; Croasdale, R. 1970: Two plinian-type eruptions in the Azores. Journal of the Geological Society $127: 17-55$.

Waters, A. C.; Fisher, R. V. 1971: Base surges and their deposits: Capelinhos and Taal volcanoes. Journal of geophysical research 76: 5594-5614.
Williams, H.; McBirney, A. T. 1969: An investigation of volcanic depressions Part II: 1 . Airfall and intrusive pyroclastic deposits; 2 . Subaerial pyroclastic flows and their deposits. Houston, Texas, N.A.S.A. Publication.

- 1979: Volcanology. San Francisco, Freeman, Cooper. 397 p. 